\title{
Interdependent Dynamics of LAI-Albedo across the Roofing Landscapes: Mongolian and Tibetan Plateaus
}

\author{
Li Tian ${ }^{1, *}$, Jiquan Chen ${ }^{2, *(1)}$ and Changliang Shao ${ }^{3}$ \\ 1 Qianyanzhou Ecological Research Station, Key Laboratory of Ecosystem Network Observation and \\ Modeling, Institute of Geographic Sciences and Natural Resources Research, Chinese Academy of Sciences, \\ Beijing 100101, China \\ 2 CGCEO and Department of Geography, Environment, and Spatial Sciences, Michigan State University, \\ East Lansing, MI 48823, USA \\ 3 National Hulunber Grassland Ecosystem Observation and Research Station \& Institute of Agricultural \\ Resources and Regional Planning, Chinese Academy of Agricultural Sciences, Beijing 100081, China; \\ shaochangliang@caas.cn \\ * Correspondence: tianli@igsnrr.ac.cn (L.T.); jqchen@msu.edu (J.C.)
}

Received: 25 May 2018; Accepted: 19 July 2018; Published: 23 July 2018

\begin{abstract}
The Mongolian Plateau (MP) and Tibetan Plateau (TP) have experienced higher-than-global average warming in recent decades, resulting in many significant changes in ecosystem structure and function. Among them are the leaf area index (LAI) and albedo, which play a fundamental role in understanding many causes and consequences of land surface processes and climate. Here, we focused on the spatiotemporal changes of LAI, albedo, and their spatiotemporal relationships on the two roofing landscapes in Eurasia. Based on the MODIS products, we investigated the spatiotemporal changes of albedo $_{(V I S, \text { NIR and SHO) }}$ and LAI from 2000 through 2016. We found that there existed a general negative logarithmic relationship between LAI and three measures of albedo on both plateaus. No significant relationship was found for LAI-albedo ${ }_{N I R}$ on the TP, due to more complex land surface canopy characteristics affected by the NIR reflection there. During 2000-2016, overall, annual mean LAI increased significantly by $119.40 \times 10^{3} \mathrm{~km}^{2}$ on the MP and by $28.35 \times 10^{3} \mathrm{~km}^{2}$ on the TP, while the decreased areas for annual mean albedo VIS were $585.59 \times 10^{3} \mathrm{~km}^{2}$ and $235.73 \times 10^{3} \mathrm{~km}^{2}$ on the MP and TP, respectively. More importantly, the LAI-albedo relationships varied substantially across the space and over time, with mismatches found in some parts of the landscapes. Substantial additional efforts with observational and/or experimental investigations are needed to explore the underlying mechanisms responsible for these relationships, including the influences of vegetation characteristics and disturbances.
\end{abstract}

Keywords: albedo; leaf area index (LAI); alpine; Eurasian continent; altitude and latitude; energy balance; global warming; land surface process

\section{Introduction}

Vegetation greening up across global terrestrial surfaces has been widely recognized as a sound indicator for understanding fundamental changes in ecosystem functions and their feedback to the regional/global climate [1,2]. This change is particularly pronounced in high latitude and altitude regions [3]. One of the coupled changes with the warming trend is local-to-regional land use that has produced very different land covers, in turn resulting in dramatically different land surface properties (e.g., land cover type, canopy structure, surface temperature, moisture, albedo, energy balances) that drive key ecosystem processes, dynamics, and functions (e.g., greenhouse gas emissions), as well as the exchanges in materials and energy between the land surface and the atmosphere [4-7]. For example, 
altered spatiotemporal trends in albedo have been argued to be a key factor for the significant increases in warming potentials at regional and global scales [2,8-11].

Surface albedo, defined as the ratio of the radiation reflected from a surface to the total incoming radiation on the Earth's surface, is directly altered and dependent of land cover types (e.g., forests vs. croplands), canopy characteristics (e.g., leaf area and distribution, foliar $\mathrm{N}$, and moisture), and length of growing season (i.e., duration of green leaves) that reflect different amounts of radiation back to the atmosphere [12]. Albedo is also indirectly altered by microclimates, especially soil and surface temperatures that emit different amounts of long wave radiation (i.e., according Botzmen's Law). In sum, the advance of vegetation greenness coverage will decrease the surface albedo, while reductions in leaf area will elevate albedo. Recent studies have also suggested positive albedo feedbacks with increased cooling of the atmosphere due to higher evapotranspiration that is associated with the changes in leaf area and temperature differences between the land surface and the atmosphere $[9,13,14]$. Nevertheless, it appears that the changes in leaf area, its spatiotemporal distributions, and the warming/cooling of the atmosphere are key processes for understanding the significance of albedo in time and space, including its role in modeling biophysical processes such as the thawing of frozen soil, deforestation, and vegetation cover that are crucial for modeling ecosystem dynamics at landscape, regional, and global scales [12].

Both modelling and observational studies suggest that climate warming will likely enhance vegetation growth in northern terrestrial ecosystems [15-18]. Several recent investigations have further emphasized the rapid changes in high altitude and high latitude areas in the Northern Hemisphere $[2,7,11,18-20]$. The Mongolian Plateau (hereafter MP) with a high altitude (>1000 m) and latitude, and the Tibetan Plateau (hereafter TP) with a high altitude ( $>4000 \mathrm{~m}$ ), have witnessed much more rapid and higher magnitude changes in vegetation and climate [9]. In this study, we focused on the spatiotemporal changes of the LAI-Albedo relationships on these two roofing landscapes of the Eurasian continent.

As an initial step for our long-term goal of understanding the interdependent LAI-Albedo relationships, land surface albedo will be independently assessed through its three bands: near infrared (NIR), visible active (VIS), and shortwave radiation (SHO). These bands represent the leaf reflection, photosynthetic absorption, and dominant energy, respectively. The data required for albedo and the leaf area index (LAI) are available through a variety of sources and approaches. Because our interest is to investigate the long-term relationships on the two large plateaus, data products from satellite remote sensing imagery are sound resources to achieve our study objectives. The albedo products from the Moderate Resolution Imaging Spectroradiometer satellite (MODIS) have a long and stable history, and have been widely used to study land cover changes and regional ecosystem functions, and the modeling of regions to the changing climate and human activities [2,10,21-24]. Specifically, we used the MODIS Bidirectional Reflectance Distribution Function (BRDF)/Albedo gap-filled snow-free product (MOD43A3(V005)) and LAI/fPAR product (MCD15A2) [21,25] to answer the following pivotal questions:

(1) Have the changes in albedo, LAI, and their relationships over the past 17 years been similar at the Mongolian and Tibetan Plateaus?

(2) Are there any significant inter- and intra- annual differences in albedo and LAI?

(3) Are the changes spatially homogeneous within each plateau? If not, how much land area has experienced significant (vs. insignificant) changes? Where are they located within a plateau?

(4) Do the three measures of albedo have similar relationships with LAI in time and space?

Both plateaus have experienced higher-than-global average climate warming [22,26]. Due to their geospatial locations, the solar irradiances between the two plateaus are significantly different. The total incoming radiation on the TP can reach $\sim 1000 \mathrm{~W} \mathrm{~m}^{-2}$ in the summer months [27], while the highest value on the MP is $\sim 900 \mathrm{~W} \mathrm{~m}^{-2}$ [28]. Both plateaus have also experienced intensified land uses including deforestation, grazing, urbanization, and agricultural expansion [29,30]. Yet, land use 
intensity and types are different across the two plateaus and in different time periods [31]. Here, we hypothesize that the spatiotemporal changes in albedo and LAI, as well as their interdependent changes in recent decades, differ significantly in time and space because of different warming trends and contrasting climate, vegetation, and historical land usage between the plateaus. As a result, there may exist "hot spots" on both plateaus where the rate of change in either albedo or LAI is substantially higher/lower than the average changes. Temporally, we hypothesize that the long-term changes in annual means are unevenly contributed from monthly values during the growing seasons, with such contributions varying by year and between the two plateaus.

\section{Materials and Methods}

\subsection{Study Areas}

The Mongolian Plateau $\left(87.8-126.0^{\circ} \mathrm{E}, 37.7-53.3^{\circ} \mathrm{N}\right)$ covers $2.75 \times 10^{6} \mathrm{~km}^{2}$ and is part of the central Asian Plateau and has an elevation of 1000-1500 m (Figure 1a). It includes two jurisdictions: Mongolia in the north and Inner Mongolia (IM) of China in the south. Four major biomes (i.e., steppe, desert, forest, and cropland) are distributed largely along the precipitation and temperature gradient, with the exception of the croplands [22]. The steppe covers $65 \%$ of the total land area (Figure 1a). Perennial green-up onset occurs in mid-to-late April and reaches maturity from early July to the end of August. In September and October, the vegetation gradually drops it leaves (i.e., vegetation senescence). The climate is predominantly semi-arid continental, with an annual mean temperature ranging from $-1.7^{\circ} \mathrm{C}$ in the meadow steppe to $5.6{ }^{\circ} \mathrm{C}$ in the desert steppe, and an annual mean precipitation of $90-433 \mathrm{~mm}$ [22]. The majority of its precipitation falls from June through August.

The Tibetan Plateau $\left(26.5-39.5^{\circ} \mathrm{N}, 78.3-103^{\circ} \mathrm{E}\right)$ covers $2.57 \times 10^{6} \mathrm{~km}^{2}$ and extends from the sub-tropical to mid-latitude regions (Figure 1a) and has an elevation of 4000-8800 m. The mean temperature in the coldest and the warmest month is approximately $-10^{\circ} \mathrm{C}$ and $10^{\circ} \mathrm{C}$, respectively [32]. Temperature and precipitation have distinct decreasing gradients from the southeast to the northwest, with the majority of precipitation falling in July-August. Three main types of grasslands (i.e., alpine meadow, alpine steppe, and alpine desert steppe) cover $63 \%$ of the plateau (Figure 1a), distributed from the southeast to the northwest along the precipitation and temperature gradient. Sparse vegetation also grows in the arid northwestern mountains with low canopy coverage. The growing season spans from late April and mid-May to late September and early October.

In this study, we focused on the changes in grasslands that cover $>60 \%$ of the plateaus. This was necessary because extremely high or low values of ET and LAI (e.g., in glaciers in the TP and forests in the MP) can potentially mask the mean values.

\subsection{MODIS Data}

The land surface products of MODIS onboard NASA's Earth Observing System's satellite Terra [21,24] and the black-sky data set for MOD43A3 (V005) BRDF/Albedo product (eight days Global 500 m SIN Grid) during 2000-2016 were used to quantify the surface reflectance of VISible spectral bands (albedo ${ }_{V I S}, 0.3-0.7 \mu \mathrm{m}$ ), Near-Infrared (albedo ${ }_{\text {NIR }}, 0.7-5.0 \mu \mathrm{m}$ ), and SHOrt wave (albedo $_{S H O}, 0.3-5.0 \mu \mathrm{m}$ ) for the growing season (May-September). Since this study aims to explore the spatiotemporal changes of albedo and their interdependent relationships with LAI on the two plateaus, it is necessary to examine the three bands independently. For grasslands, albedo ${ }_{V I S}$ during the onset of new growth decreases as the green leaves absorb more shortwave radiation through photosynthesis, while albedo $\mathrm{NIR}_{\mathrm{N}}$ is unlikely to change. Following the leaf extension, both photosynthetically-active radiation (PAR) and fraction of PAR (fPAR) will remain high, resulting in reduced albedo albedo $_{S H O}$. Theoretically, the leaf expansion will increase canopy scattering and increase albedo ${ }_{N I R}$ reflectance. This will also increase land surface roughness that in turn increases diffuse reflection,

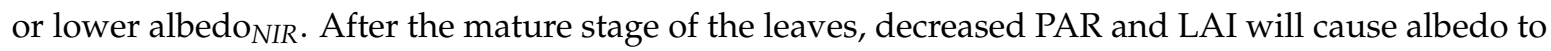
increase. In addition, albedo ${ }_{S H O}$ reflects the exchanges of energy and may therefore show different 
dynamics with LAI. The LAI/fPAR product is coded as the MCD15A2 eight-day (2000-2016), with a $1-\mathrm{km}$ spatial resolution.
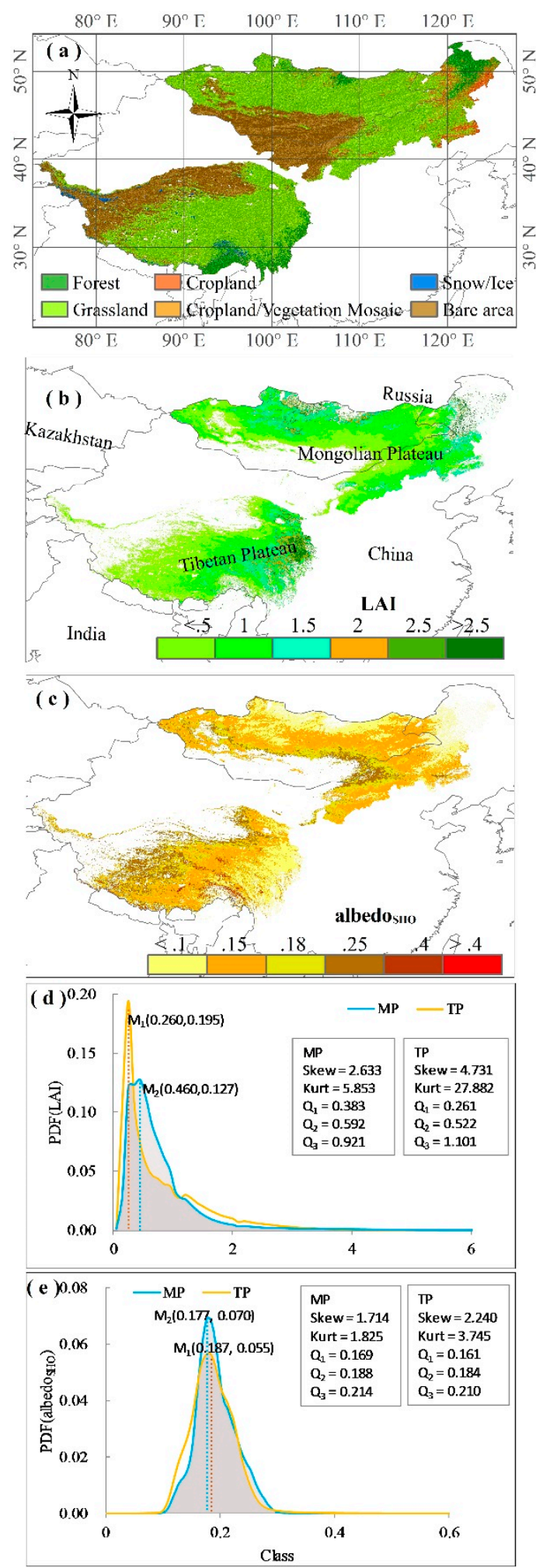

Figure 1. (a) The spatial distributions of land cover types. (b) The average annual LAI during 2000-2016. (c) The average annual albedo ${ }_{S H O}$ on the two plateaus during 2000-2016. (d-e) The probability density function (PDF) for LAI and albedosHO. 
The two products of LAI and albedo were further improved by filtering out noises through smooth processing that may have resulted from cloud contamination and topographic differences using the subset tool to restrict the analysis. Altogether, we included 20 images produced between the day of year (DOY) 121 and 273 (1 May to 30 September). For analysis of the correlation between albedo and LAI, the products of the three bands for albedo were resampled to a spatial resolution of $1 \mathrm{~km}$ using the Python code of Arcpy Resample management to match with the LAI data. Our initial examination of the relationship between albedo and LAI demonstrated that the maximum LAI matched well with the minimum albedo. Consequently, we compiled the monthly minimum albedo and maximum LAI for each month. For example, albedo in May was extracted as the minimum values among values of DOY $121,129,137$, and 145 for each pixel; the monthly albedo $o_{\text {min }}$ and the annual albedomean in the growing season were calculated using Equations (1) and (2), respectively; and the monthly $L A I_{\max }$ and annual $L A I_{\text {mean }}$ were calculated using Equations (3) and (4), respectively.

\subsection{Quantitative Metrics and Analysis}

The annual averages of the three bands of albedo $_{\text {mean }}$ and the monthly minimum albedo ${ }_{\text {min }}$ are calculated using Equations (1) and (2), respectively:

$$
\begin{aligned}
\operatorname{albedo}_{(V I S, N I R, S H O) m i n} & =\operatorname{Min}\left(\operatorname{albedo}_{(V I S, N I R, S H O) m i n, i}\right) \\
\operatorname{albedo}_{(V I S, N I R, S H O) m e a n} & =\frac{1}{5} \sum_{i=1}^{5} \operatorname{albedo}_{(V I S, N I R, S H O) m i n}
\end{aligned}
$$

where albedo $(V I S, N I R, S H O)$ min is the minimum albedo value of each month of the three bands, respectively; and albedo $(V I S, N I R, S H O)$ mean is the annual mean value in the growing season of the three bands, respectively. $i$ denotes the months of May, June, July, August, and September. Similarly, the month $L A I_{\max }$ and annual $\mathrm{LAI}_{\text {mean }}$ are calculated as:

$$
\begin{aligned}
\operatorname{LAI}_{\text {max }} & =\operatorname{Max}\left(\operatorname{LAI}_{\text {max }, i}\right) \\
\mathrm{LAI}_{\text {mean }} & =\frac{1}{5} \sum_{i=1}^{5} \mathrm{LAI}_{\text {max }}
\end{aligned}
$$

where $\mathrm{LAI}_{\max }$ is the maximum LAI of each month; $i$ represents the months of May, June, July, August, and September; and $\mathrm{LAI}_{\text {mean }}$ is the annual mean value in the growing season.

To explore the inter-annual changes in albedo and LAI, we separated the growing season by

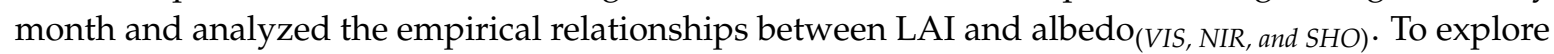
the intra-annual dynamics and changing trends, we calculated the Z-score normalization of albedo and LAI to estimate the rate of change (i.e., the slope of a linear trend) for each pixel, and to extract the statistically significant points $(p<0.05)$. Within the ArcGIS 10.2 platform, the pixel number and value of the annual mean LAI and albedo ${ }_{S H O}$ were retrieved to delineate extreme high/low values as the "hot spots" of the changes based on the probability density function (PDF) using the R Package. For the

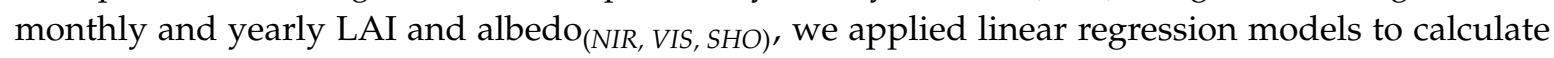
the coefficient of variation (CV) for the two plateaus by the origin data in order to quantify their inter-annual variations. Finally, we used natural logarithmic regression to examine the relationship between annual albedo $(N I R, V I S, S H O)$ and LAI on the two plateaus by average annual LAI class to test our hypothesis.

\section{Results}

\subsection{The Spatiotemporal Changes in LAI \& Albedo}

Grassland is the major cover type among the six cover types on both plateaus, accounting for $65 \%$ and $63 \%$ of the Mongolian and Tibetan Plateau, respectively (Figure 1a). On the TP, alpine meadow is distributed in the southeast region and the alpine steppe dominates the northwest (Figure 1a), resulting 
in a gradual decrease in LAI (Figure 1b) and increasing albedo ${ }_{S H O}$ (Figure 1c) from the southeast to the northwest. On the MP, the Eurasian steppe includes meadow, meadow steppe, typical steppe, desert steppe, and desert from the southeast (i.e., Inner Mongolia) to the north (Mongolia) before it reaches the desert (Figure 1a), which is coupled with a decrease in LAI (Figure 1b) and increasing albedo ${ }_{S H O}$ (Figure 1c) along the same gradient.

The long-term mean $( \pm$ std $)$ of LAI on the MP and the TP was $0.728( \pm 0.63)$ and 0.698 $( \pm 0.71)$, respectively, and albedo $S H O$ was $0.193( \pm 0.035)$ and $0.188( \pm 0.040)$, respectively (Table 1$)$. The probability density function (PDF) indicates that both LAI and albedosHO were left-skewed. Because we focused on the changes in grassland vegetation type for the two plateaus, the value of LAI focused on a very narrow frequency range for both plateaus; comparing two plateaus, the TP showed a stronger level of skewedness for annual LAI and albedo ${ }_{S H O}$ (Figure 1d,e). The mode value of PDF (LAI) was significantly higher for the TP than that for the MP, while there was no significant difference in the mode values of albedo ${ }_{S H O}$. For LAI, a greater number of pixels fell in the $<0.36$ range for the TP than the MP, but the TP had fewer pixels in LAI classes of 0.36-1.22 (Figure 1d).

Table 1. The average annual and standard deviation (std) of LAI and albedo $(N I R, V I S, S H O)$ during 2000-2016 by average annual LAI class on the Mongolian Plateau (MP) and the Tibetan Plateau (TP).

\begin{tabular}{ccccccccc}
\hline \multirow{2}{*}{ LAI Class } & \multicolumn{4}{c}{ MP } & \multicolumn{5}{c}{ TP } \\
\cline { 2 - 9 } & LAI & VIS & SHO & NIR & LAI & VIS & SHO & NIR \\
\hline$<0.5$ & 0.31 & 0.158 & 0.213 & 0.286 & 0.22 & 0.155 & 0.204 & 0.254 \\
$0.5-1.0$ & 0.72 & 0.101 & 0.187 & 0.267 & 0.74 & 0.099 & 0.174 & 0.243 \\
$1.0-1.5$ & 1.21 & 0.080 & 0.169 & 0.246 & 1.26 & 0.074 & 0.163 & 0.242 \\
$1.5-2.0$ & 1.72 & 0.064 & 0.153 & 0.235 & 1.73 & 0.062 & 0.158 & 0.245 \\
$2.0-2.5$ & 2.23 & 0.057 & 0.145 & 0.228 & 2.24 & 0.057 & 0.160 & 0.253 \\
$>2.5$ & 3.47 & 0.050 & 0.143 & 0.226 & 3.14 & 0.054 & 0.164 & 0.264 \\
Mean & 0.73 & 0.111 & 0.193 & 0.275 & 0.70 & 0.123 & 0.188 & 0.249 \\
Std & 0.63 & 0.036 & 0.035 & 0.042 & 0.71 & 0.058 & 0.040 & 0.042 \\
\hline
\end{tabular}

The long-term changes (i.e., slopes of the linear models) of annual and monthly LAI and

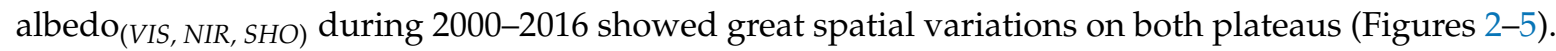
For the annual LAI, the regions with increasing LAI on the TP were mostly found in the northeast, while it decreased in the southeast (Figure 2a). Overall, we found that $57.41 \times 10^{3} \mathrm{~km}^{2}$ on the TP experienced significant change in LAI, which included $28.35 \times 10^{3} \mathrm{~km}^{2}$ and $29.06 \times 10^{3} \mathrm{~km}^{2}$ that experienced increasing and decreasing change, respectively (Table 2). On the MP, however, $128.19 \times 10^{3} \mathrm{~km}^{2}$ grassland of LAI experienced significant change, including an increase for the majority of the land area of $119.40 \times 10^{3} \mathrm{~km}^{2}(96.75 \%)$, with only a few patches $\left(8.70 \times 10^{3} \mathrm{~km}^{2}\right.$, or $3.25 \%$ ) showing a decreasing trend. More interestingly, the monthly changes in LAI unevenly contributed to these long-term changes in annual LAI (Figure 2, Table 2). For the TP, the LAI increase in May $\left(61.86 \times 10^{3} \mathrm{~km}^{2}\right.$, or $\left.95.14 \%\right)$ was more pronounced than that during June-September $\left(31.86 \times 10^{3} \mathrm{~km}^{2}, 27.93 \times 10^{3} \mathrm{~km}^{2}, 29.45 \times 10^{3} \mathrm{~km}^{2}, 11.93 \times 10^{3} \mathrm{~km}^{2}\right.$, respectively); whereas, on the MP, the increasing trend seemed more obvious in June $\left(123.10 \times 10^{3} \mathrm{~km}^{2}\right.$, or $\left.98.39 \%\right)$ and July $\left(94.30 \times 10^{3} \mathrm{~km}^{2}\right.$, or $\left.75.82 \%\right)$ than in May $\left(52.80 \times 10^{3} \mathrm{~km}^{2}\right)$, August $\left(68.20 \times 10^{3} \mathrm{~km}^{2}\right)$, and September $\left(64.30 \times 10^{3} \mathrm{~km}^{2}\right)($ Table 2$)$. 
Table 2. The total area that experienced significant change in LAI and albedo $(S H O, N I R, V I S)$ on the two plateaus by year and month during 2000-2016; the significant change area (Total) $\left(\mathrm{km}^{2}\right)$ is also expressed as its percentage (\%) to the total all-changed area; the significant decreasing (Decreasing) and significant increasing (Increasing) areas $\left(\mathrm{km}^{2}\right)$ are not provided with their portions.

\begin{tabular}{|c|c|c|c|c|c|c|c|c|}
\hline Var & Loc & Sig. Area & Annual & May & June & July & Aug. & Sep. \\
\hline \multirow{6}{*}{ LAI } & \multirow{3}{*}{$\mathrm{MP}$} & $\begin{array}{c}\text { Total }\left(10^{3}\right. \\
\left.\mathrm{km}^{2}\right) \\
(\%)\end{array}$ & $\begin{array}{l}128.19 \\
(21.35)\end{array}$ & $\begin{array}{c}57.12 \\
(11.96)\end{array}$ & $\begin{array}{l}100.63 \\
(21.07)\end{array}$ & $\begin{array}{c}80.81 \\
(16.92)\end{array}$ & $\begin{array}{c}62.59 \\
(13.11)\end{array}$ & $\begin{array}{c}61.36 \\
(12.85)\end{array}$ \\
\hline & & Decreasing & 8.70 & 23.90 & 4.10 & 7.80 & 10.10 & 16.10 \\
\hline & & Increasing & 119.40 & 52.80 & 123.10 & 94.30 & 68.20 & 64.30 \\
\hline & \multirow{3}{*}{$\mathrm{TP}$} & $\begin{array}{c}\text { Total }\left(10^{3}\right. \\
\left.\mathrm{km}^{2}\right) \\
(\%)\end{array}$ & $\begin{array}{c}57.41 \\
(14.69)\end{array}$ & $\begin{array}{c}65.03 \\
(16.64)\end{array}$ & $\begin{array}{l}38.39 \\
(9.83)\end{array}$ & $\begin{array}{c}47.92 \\
(12.26)\end{array}$ & $\begin{array}{c}48.00 \\
(12.28)\end{array}$ & $\begin{array}{c}42.96 \\
(11.00)\end{array}$ \\
\hline & & Decreasing & 29.06 & 3.16 & 6.53 & 19.99 & 18.55 & 31.03 \\
\hline & & Increasing & 28.35 & 61.86 & 31.86 & 27.93 & 29.45 & 11.93 \\
\hline \multirow{6}{*}{ Albedo $_{N I R}$} & \multirow{3}{*}{ MP } & $\begin{array}{c}\text { Total }\left(10^{3}\right. \\
\left.\mathrm{km}^{2}\right) \\
(\%)\end{array}$ & $\begin{array}{l}639.42 \\
(33.45)\end{array}$ & $\begin{array}{l}478.36 \\
(25.39)\end{array}$ & $\begin{array}{l}469.16 \\
(24.84)\end{array}$ & $\begin{array}{l}464.35 \\
(24.40)\end{array}$ & $\begin{array}{l}255.66 \\
(13.40)\end{array}$ & $\begin{array}{l}481.96 \\
(25.33)\end{array}$ \\
\hline & & Decreasing & 441.64 & 289.87 & 313.19 & 323.75 & 154.56 & 418.98 \\
\hline & & Increasing & 197.78 & 188.48 & 155.96 & 140.60 & 101.10 & 62.98 \\
\hline & \multirow[t]{3}{*}{$\mathrm{TP}$} & $\begin{array}{c}\text { Total }\left(10^{3}\right. \\
\left.\mathrm{km}^{2}\right) \\
(\%)\end{array}$ & $\begin{array}{l}330.58 \\
(19.34)\end{array}$ & $\begin{array}{c}148.03 \\
(11.00)\end{array}$ & $\begin{array}{l}149.08 \\
(12.21)\end{array}$ & $\begin{array}{l}148.03 \\
(11.68)\end{array}$ & $\begin{array}{l}115.74 \\
(10.02)\end{array}$ & $\begin{array}{l}190.03 \\
(11.68)\end{array}$ \\
\hline & & Decreasing & 249.82 & 117.64 & 95.54 & 117.64 & 63.43 & 135.01 \\
\hline & & Increasing & 80.76 & 30.39 & 53.54 & 30.39 & 52.30 & 55.02 \\
\hline \multirow{6}{*}{ Albedo $_{V I S}$} & \multirow{3}{*}{ MP } & $\begin{array}{c}\text { Total }\left(10^{3}\right. \\
\left.\mathrm{km}^{2}\right) \\
(\%)\end{array}$ & $\begin{array}{l}605.48 \\
(31.68)\end{array}$ & $\begin{array}{l}412.24 \\
(21.85)\end{array}$ & $\begin{array}{l}420.77 \\
(22.31)\end{array}$ & $\begin{array}{l}434.24 \\
(22.84)\end{array}$ & $\begin{array}{l}378.71 \\
(19.85)\end{array}$ & $\begin{array}{l}456.77 \\
(24.00)\end{array}$ \\
\hline & & Decreasing & 585.59 & 366.15 & 403.18 & 413.06 & 354.84 & 442.86 \\
\hline & & Increasing & 19.89 & 46.09 & 17.59 & 21.18 & 23.86 & 13.91 \\
\hline & \multirow[t]{3}{*}{$\mathrm{TP}$} & $\begin{array}{c}\text { Total }\left(10^{3}\right. \\
\left.\mathrm{km}^{2}\right) \\
(\%)\end{array}$ & $\begin{array}{l}283.53 \\
(16.59)\end{array}$ & $\begin{array}{c}197.08 \\
(10.44)\end{array}$ & $\begin{array}{l}130.54 \\
(11.01)\end{array}$ & $\begin{array}{l}179.60 \\
(14.38)\end{array}$ & $\begin{array}{l}143.54 \\
(12.79)\end{array}$ & $\begin{array}{c}157.62 \\
(9.70)\end{array}$ \\
\hline & & Decreasing & 235.73 & 183.17 & 85.95 & 152.02 & 97.95 & 122.69 \\
\hline & & Increasing & 47.80 & 13.90 & 44.59 & 27.58 & 45.59 & 34.93 \\
\hline \multirow{6}{*}{ Albedo $_{S H O}$} & \multirow{3}{*}{ MP } & $\begin{array}{c}\text { Total }\left(10^{3}\right. \\
\left.\mathrm{km}^{2}\right) \\
(\%)\end{array}$ & $\begin{array}{l}597.17 \\
(31.24)\end{array}$ & $\begin{array}{l}468.47 \\
(24.89)\end{array}$ & $\begin{array}{l}431.68 \\
(22.94)\end{array}$ & $\begin{array}{l}429.77 \\
(22.62)\end{array}$ & $\begin{array}{l}324.27 \\
(17.00)\end{array}$ & $\begin{array}{l}426.51 \\
(22.43)\end{array}$ \\
\hline & & Decreasing & 495.83 & 359.54 & 360.11 & 355.50 & 242.20 & 389.51 \\
\hline & & Increasing & 101.34 & 108.93 & 71.56 & 74.27 & 82.07 & 36.99 \\
\hline & \multirow[t]{3}{*}{$\mathrm{TP}$} & $\begin{array}{c}\text { Total }\left(10^{3}\right. \\
\left.\mathrm{km}^{2}\right) \\
(\%)\end{array}$ & $\begin{array}{l}290.79 \\
(17.01)\end{array}$ & $\begin{array}{l}179.78 \\
(13.54)\end{array}$ & $\begin{array}{l}130.97 \\
(11.39)\end{array}$ & $\begin{array}{l}116.43 \\
(9.54)\end{array}$ & $\begin{array}{l}137.26 \\
(12.46)\end{array}$ & $\begin{array}{l}173.21 \\
(10.75)\end{array}$ \\
\hline & & Decreasing & 224.23 & 162.09 & 84.32 & 79.43 & 80.19 & 121.13 \\
\hline & & Increasing & 66.56 & 17.68 & 46.64 & 37.00 & 57.07 & 52.08 \\
\hline
\end{tabular}



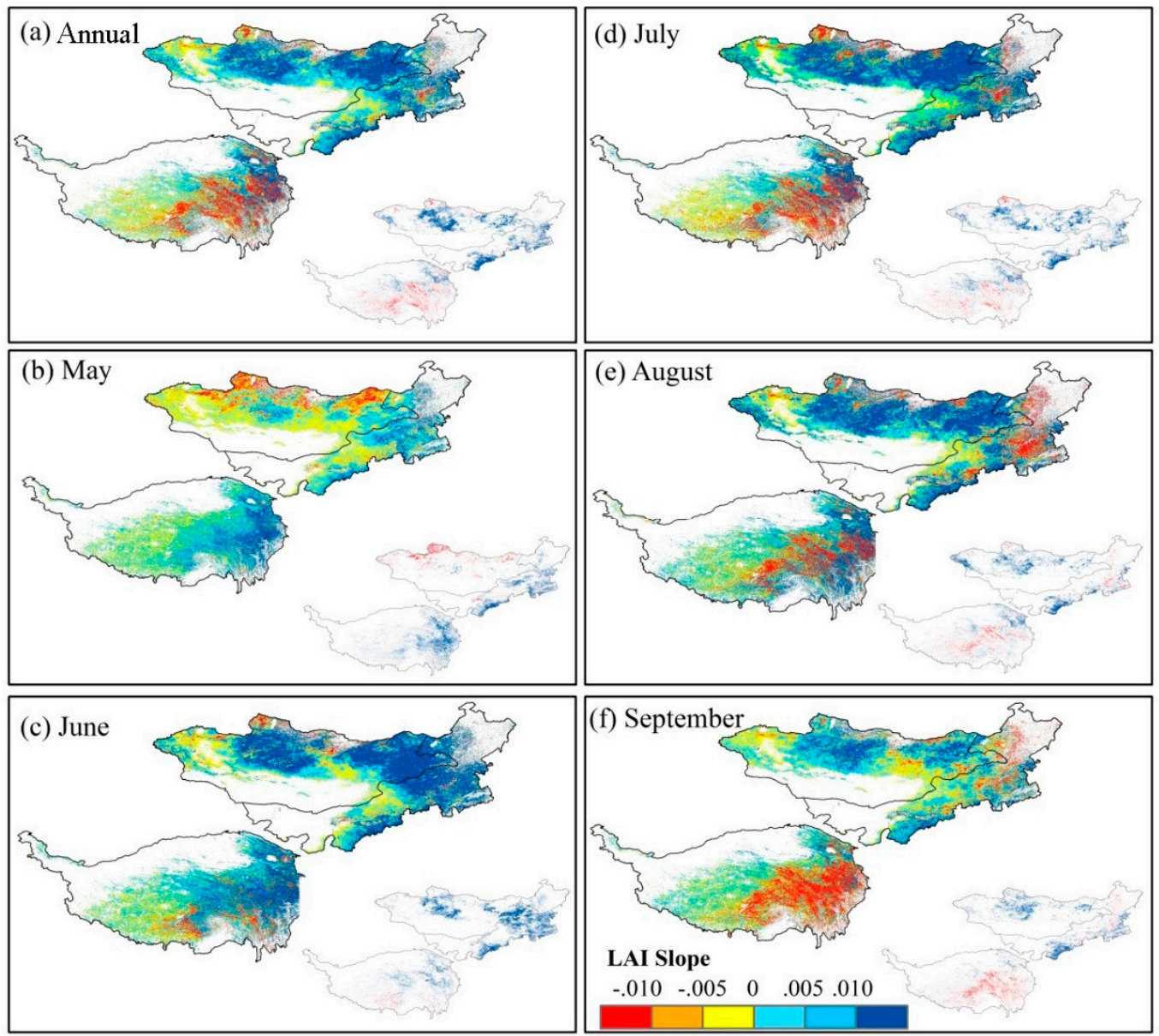

Figure 2. Spatial distributions of the changing trends for LAI during 2000-2016 in the growing season (Annual, May, June, July, August, and September). The inset maps show the significant $(p<0.05)$ increases in blue and the significant decreases in red.

Large spatial variations in the long-term changing trends were also detected for three measures of albedo on both plateaus; however, the spatial patterns of the changing trends were not the same for both plateaus (Figures 3-5). Although there were no significant differences in annual albedo between the two plateaus (Table 2), the rates of change of the three albedo terms seemed stronger for the MP than for the TP. On the MP, the percentage of grassland that experienced significant increasing/decreasing trends in albedo $_{N I R}$, albedo $_{V I S}$, and albedo ${ }_{S H O}$ was $33.45 \%, 31.68 \%$, and $31.24 \%$, respectively; this figure was $19.34 \%, 16.59 \%$, and $17.01 \%$, respectively, on the TP (Table 2). It is worth noting the albedo changes in the southeastern MP where very strong decreases in albedo NIR $_{\text {(Figure } 3 \text { ) }}$ and albedo $_{S H O}$ (Figure 5) were detected, whereas more widespread decreases in albedo ${ }_{V I S}$ appeared for the whole MP (Figure 4). These differences among the annual albedo changes were not apparent on the TP. 

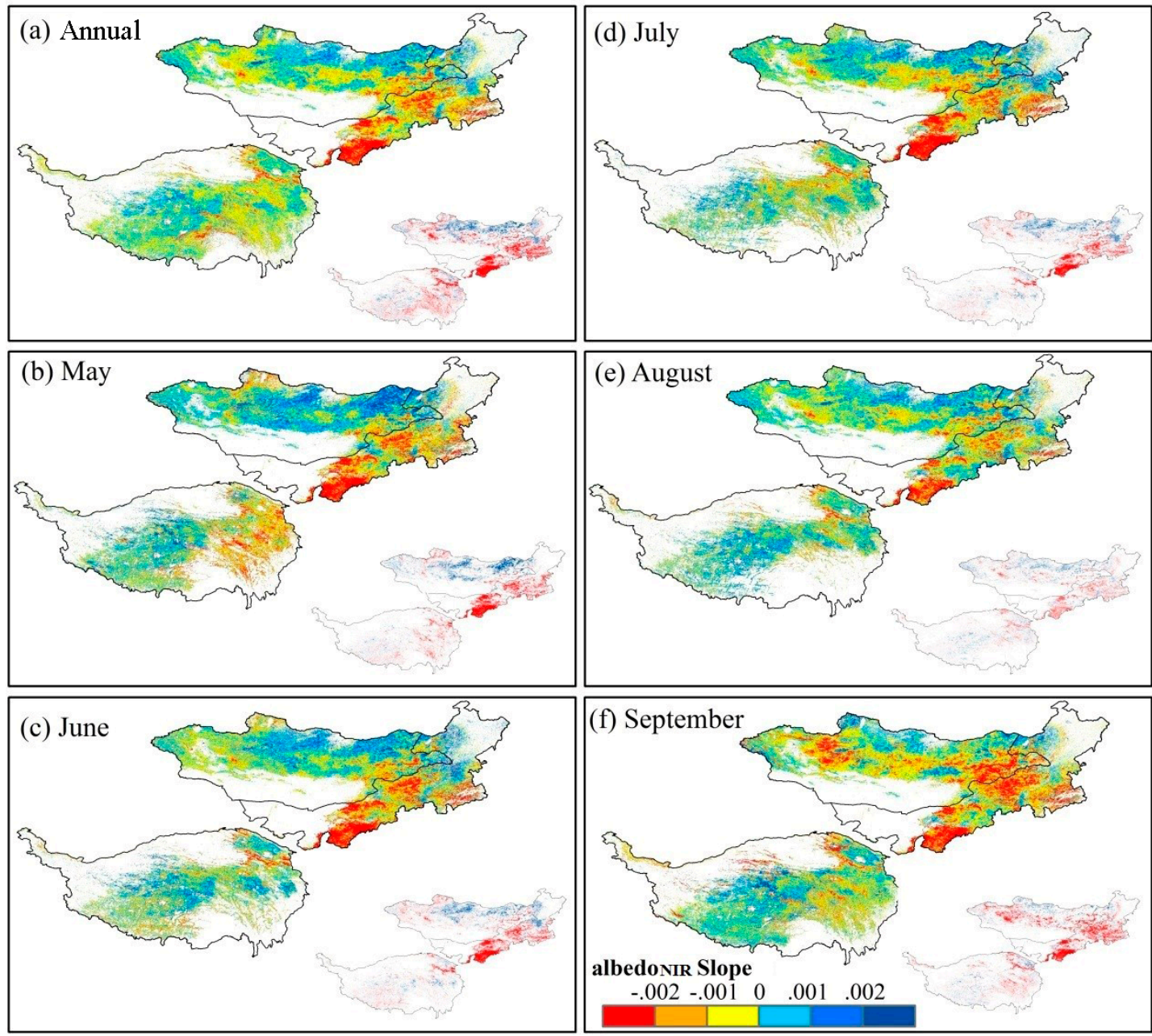

Figure 3. Spatial distributions of the changing trends for albedo ${ }_{\text {NIR }}$ during 2000-2016 in the growing season (Annual, May, June, July, August, and September). The inset maps show the significant increasing $(p<0.05)$ (blue) or decreasing (red) trends at a significant level of $p<0.05$.

Similar to LAI, the annual change in albedo was contributed to differently by month. For the MP, the change in albedo ${ }_{N I R}$ during May-August matched well with that of annual albedo ${ }_{N I R}$, but not for September. Whereas for the TP, May had the only monthly spatial change that matched well with the annual means (Figure $3 \mathrm{~b}-\mathrm{f}$ ). For albedo $_{V I S}$, the spatial distribution of the annual mean on the MP matched well with that during June-September, but not with that in May. On the TP, there appeared no good matches with any month (Figure $4 \mathrm{~b}-\mathrm{f}$ ). For albedo ${ }_{S H O}$, there were no good matches with any monthly changes on either plateau (Figure 5b-f). Additionally, the amount of land area that experienced significant decreasing or increasing changes at the monthly scale was not consistent by month, plateau, or among the three measures of albedo (Table 2). For example, the total land area with decreasing albedo ${ }_{S H O}$ on the MP was the highest in September $\left(389.51 \times 10^{3} \mathrm{~km}^{2}\right.$, or $\left.91.32 \%\right)$ and the lowest in August $\left(242.20 \times 10^{3} \mathrm{~km}^{2}\right.$, or $\left.74.69 \%\right)$, while this figure on the TP was the highest in May $\left(162.09 \times 10^{3} \mathrm{~km}^{2}\right.$, or $\left.90.16 \%\right)$ and the lowest in July $\left(79.43 \times 10^{3} \mathrm{~km}^{2}\right.$, or $\left.68.22 \%\right)$ (Table 2). 

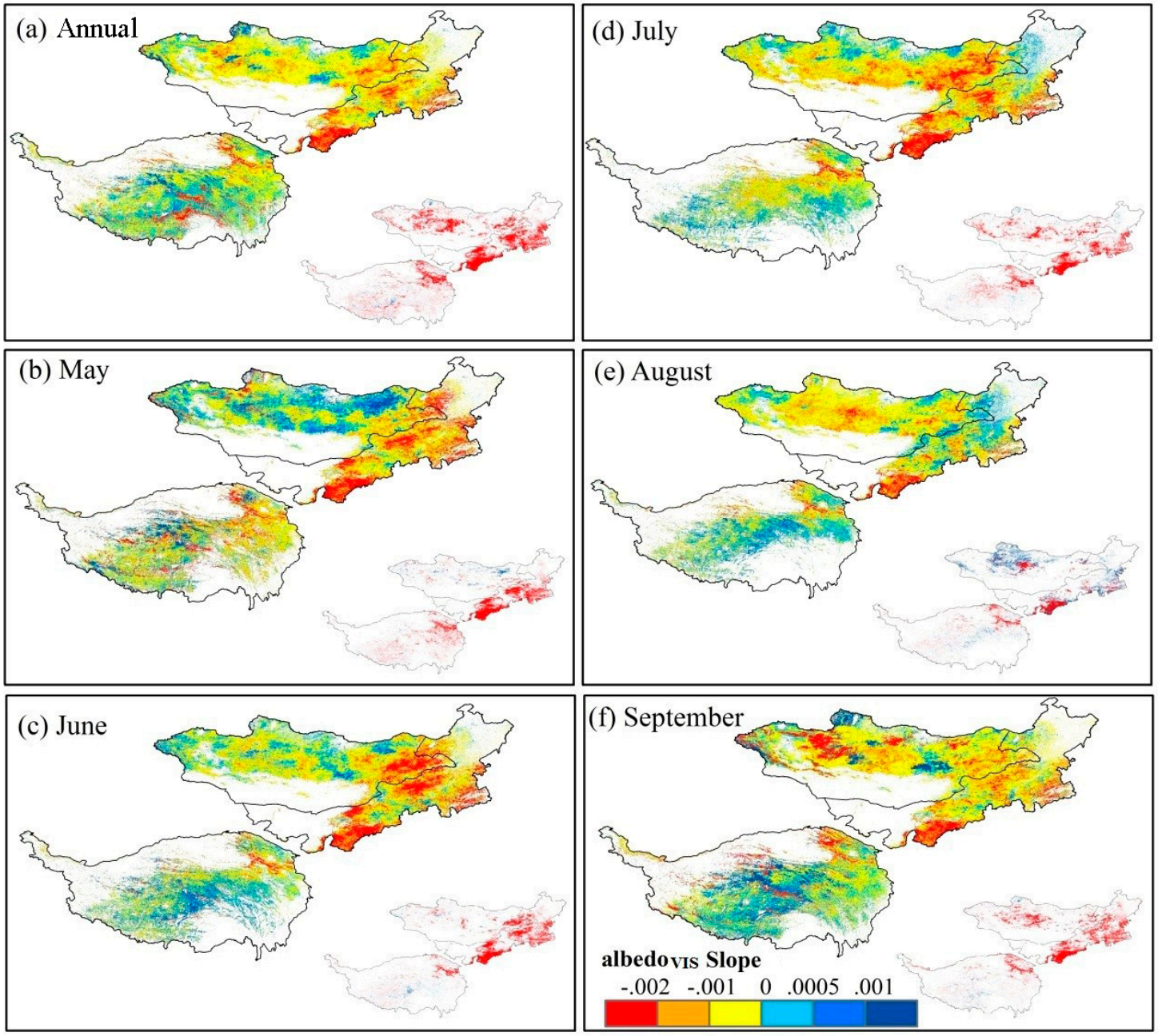

Figure 4. Spatial distributions of the changing trends for albedo $_{V I S}$ during the growing season (Annual, May, June, July, August, and September); the inset map shows the significant increasing $(p<0.05)$ (blue) or decreasing (red) trends at a significance level of $p<0.05$.

\subsection{Inter-Annual Variations of LAI and Albedo}

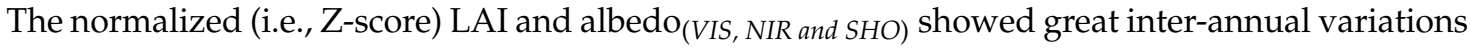
by year and month, as well as between the plateaus (Figures 6 and 7). For LAI, the Z-score on the MP had a higher mean and variation than that on the TP $\left(\mathrm{CV}_{\mathrm{MP}}=0.091,0.119,0.157,0.126,0.108,0.192\right.$; $\mathrm{CV}_{\mathrm{TP}}=0.049,0.049,0.119,0.061,0.083$ and 0.121 for annual, May, June, July, August, and September, respectively) (Figure 6).

On the TP, the LAI showed a significant increase in May (Slope $=0.152, p=0.001$ ) (Figure 6b); on the MP, the LAI showed a significant increase at the annual scale (slope $=0.121, p=0.009$ ), as well as for the months of June (slope $=0.117, p=0.013$ ), July (slope $=0.105, p=0.029$ ), and August (slope $=0.082, p=0.037$ ) (Figure 6a,c-e). The absolute value of the slope on the MP was higher than that on the TP, except in May (Figure 6). It is also worth noting that the vegetation improvement in LAI on the MP was more apparent than that on the TP during the study period. Over the 17-year study period, there were seven years when the Z-score was above or below the long-term annual LAI mean on MP. There were also seven years when the Z-score was above and below the long-term mean on the TP; however, these years were not the same as those on the MP (Figure 6a). When examined by month, the inter-annual variation (i.e., $\mathrm{CV}$ values) on the MP was higher than that on the $\mathrm{TP}$, and the long-term change of the monthly means also differed between the plateaus (Figure $6 \mathrm{~b}-\mathrm{f}$ ). Additionally, a large deviation in the LAI of May on the MP was found for 2002, 2006, 2008, and 2014, while it occurred 
in 2000, 2001, and 2006 on the TP. These differences for other months were not consistent on either plateau (Figure 6c-f). Finally, it seemed that: (1) LAI on both plateaus was reduced in the June of 2001 and September of 2014; (2) LAI in May-June of 2014 on the MP was the highest; (3) LAI values in June-August on the TP were low; and (4) LAI of all five months in 2007 was below the average on the MP.
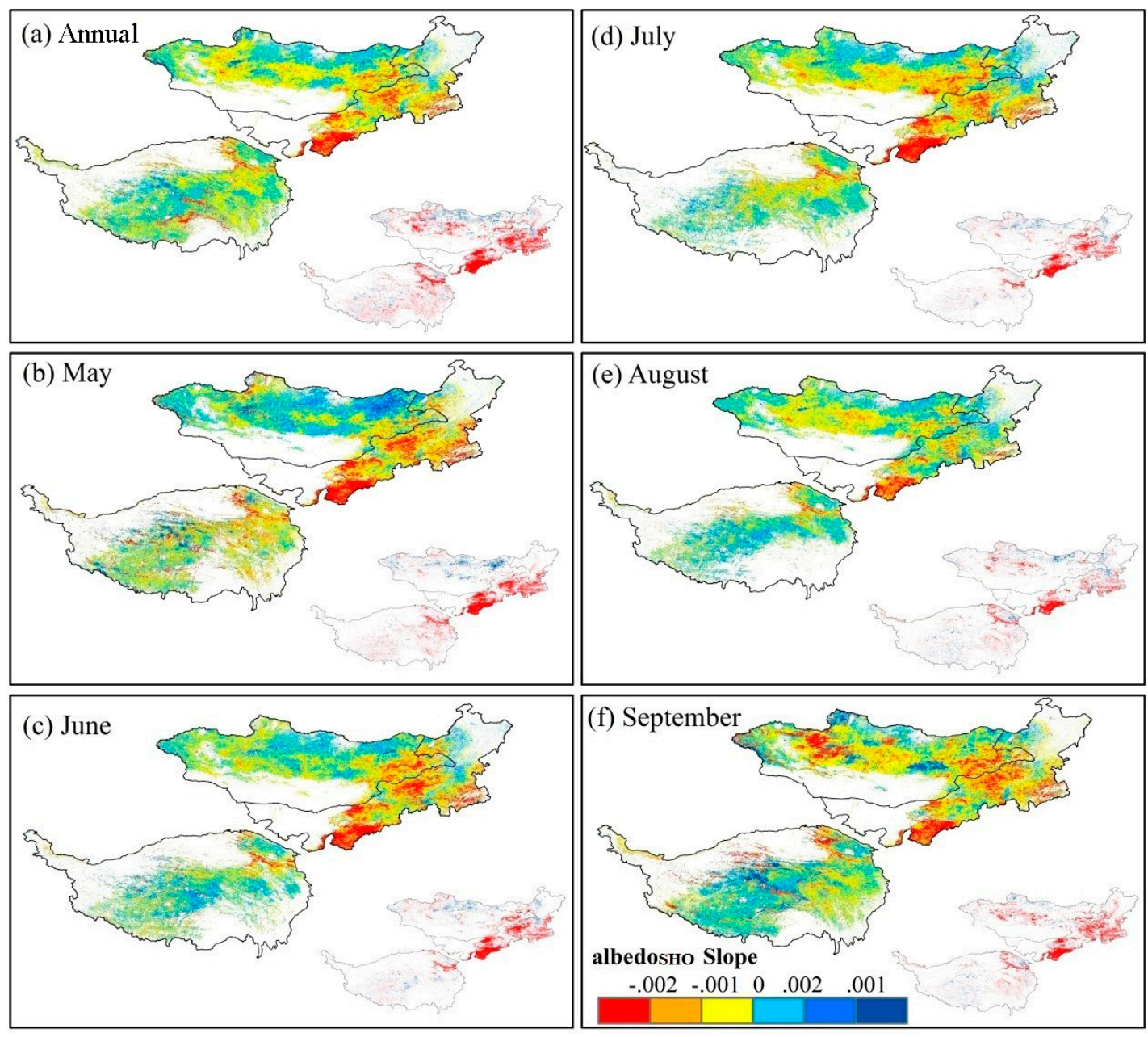

Figure 5. Spatial distributions of the changing trends in albedo ${ }_{S H O}$ during the growing season (Annual, May, June, July, August, and September); the inset map shows significant increases (blue) and decreases (red) $(p<0.05)$.

The three measures of albedo at yearly and monthly time scales showed decreasing trends and large inter-annual variations over the study period, with similar changes among the three albedo measures within the plateaus, but different between the plateaus (Figure 7, Table 3). Between the two plateaus, the Z-score on the MP was higher than that on the TP $\left(\mathrm{CV}_{\mathrm{MP}}=0.022,0.023,0.025,0.026\right.$, 0.029, 0.031; $\mathrm{CV}_{\mathrm{TP}}=0.012,0.040,0.017,0.015,0.020$, and 0.026 for annual, May, June, July, August, and September, respectively). The extra-annual change trend for the three bands albedo on the two plateaus had a negative slope (Table 3), and for the annual albedo VIS on the two plateaus, showed a significant decreasing trend (slope $=-0.161 p=0.001$; slope $=-0.137, p=0.002$ ) for TP and MP, respectively. In addition, for MP, June, July, and September all showed significant decreases (Table 3), with slopes and P values of $-0.108(p=0.023),-0.13(p=0.004)$, and $-0.126(p=0.006)$ for June, July, and September, respectively. For the annual albedo $_{N I R}$, as well as that in May and June, on the TP, the slope was $-0.122(p=0.009),-0.147(p=0.001)$, and $-0.115(p=0.015)$, respectively, which were lower values than those on the MP. For the MP, only June and September showed significant negative 
changes (slope $=-0.098, p=0.044$; slope $=-0.110, p=0.020)$ ), respectively $($ Table 3$)$. For the abledo ${ }_{S H O}$, the TP had a lower slope value both annually and in May, with significant change found for the annual, May, and July values (slope $=-0.149, p=0.001$; slope $=-0.098, p=0.043$; and slope $=-0.103, p=0.033$, respectively). However, on the MP, only July and September showed a significant decrease, with a slope of $-0.119(p=0.011)$ and $-0.112(p=0.018)$, respectively (Table 3$)$. In sum, it appeared that there was a greater overall decreasing trend on the TP than that on the MP, although the LAI increased faster on the MP than on the TP (Figures 6 and 7, Table 3). The anomaly in annual albedo was generally above the long-term mean before 2007 on the TP and 2010 on MP, except 2003 for the TP and 2004 for the MP (Figure 7a). During 2006-2011, the MP witnessed an overall higher deviation from the mean than the TP. An extremely low Z-score was found in 2013 on the TP. Similar to LAI, the long-term changes in monthly albedo values had different contributions to the annual values, regardless of the decreasing trends for all months (Figure $7 \mathrm{~b}-\mathrm{f}$ ). For example, the low annual albedo on the MP in 2003 seemed to be related to the extremely low value in July-September, whereas another extremely low value in 2013 was contributed from those from July through August.
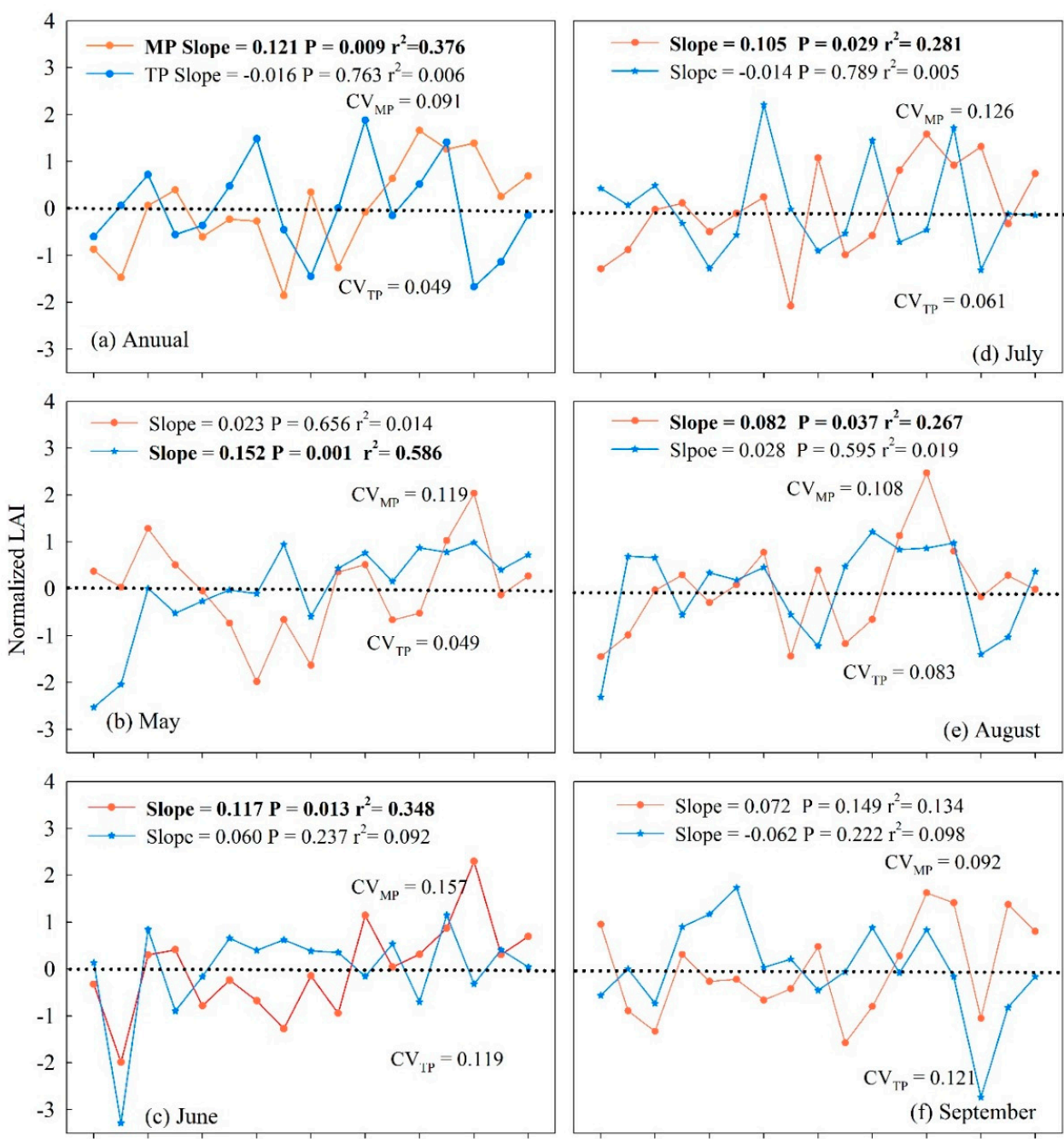

200020022004200620082010201220142016200020022004200620082010201220142016 Year

Figure 6. The trends of the normalized LAI by year and month on the grassland vegetated Mongolian and Tibetan plateau. 

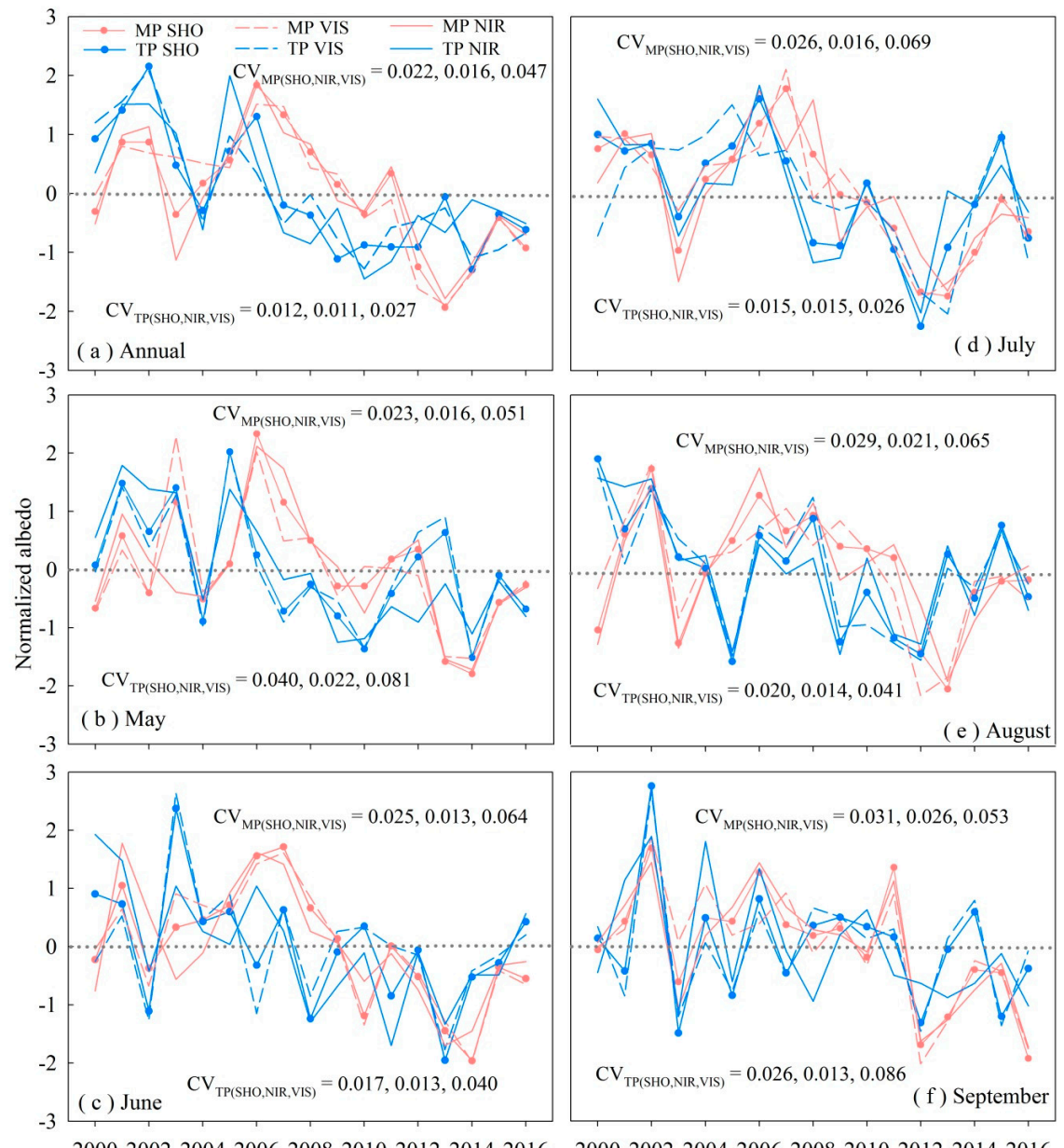

200020022004200620082010201220142016200020022004200620082010201220142016 Year

Figure 7. The trends of the normalized albedo $(N I R, V I S, S H O)$ by year and month for the grasslands of the Mongolian and the Tibetan plateau during 2000-2016.

Table 3. The regression trends in the normalized average annual albedo and minimum albedo by month on the vegetated grasslands of the Mongolian and Tibetan plateau during 2000-2016. The bold number reached a statistical significant level.

\begin{tabular}{|c|c|c|c|c|c|c|c|c|}
\hline Var & Loc & & Annual & May & June & July & August & September \\
\hline \multirow{6}{*}{$\mathrm{SHO}$} & \multirow{3}{*}{$\mathrm{TP}$} & Slope & -0.149 & -0.098 & -0.085 & -0.103 & -0.092 & -0.048 \\
\hline & & $p$ & 0.001 & 0.043 & 0.185 & 0.033 & 0.060 & 0.348 \\
\hline & & $\mathrm{R}^{2}$ & 0.563 & 0.247 & 0.085 & 0.268 & 0.217 & 0.060 \\
\hline & \multirow{3}{*}{ MP } & Slope & -0.115 & -0.073 & -0.108 & -0.119 & -0.059 & -0.112 \\
\hline & & $p$ & 0.151 & 0.143 & 0.296 & 0.011 & 0.250 & 0.018 \\
\hline & & $\mathrm{R}^{2}$ & 0.334 & 0.137 & 0.024 & 0.360 & 0.087 & 0.318 \\
\hline \multirow{6}{*}{ NIR } & \multirow{3}{*}{$\mathrm{TP}$} & Slope & -0.122 & -0.147 & -0.115 & -0.090 & -0.110 & -0.093 \\
\hline & & $p$ & 0.009 & 0.001 & 0.015 & 0.067 & 0.027 & 0.058 \\
\hline & & $\mathrm{R}^{2}$ & 0.377 & 0.550 & 0.334 & 0.206 & 0.286 & 0.219 \\
\hline & \multirow{3}{*}{ MP } & Slope & -0.092 & -0.072 & -0.098 & -0.091 & -0.044 & -0.11 \\
\hline & & $p$ & 0.059 & 0.151 & 0.044 & 0.065 & 0.397 & 0.020 \\
\hline & & $\mathrm{R}^{2}$ & 0.217 & 0.132 & 0.244 & 0.209 & 0.048 & 0.311 \\
\hline \multirow{6}{*}{ VIS } & \multirow{3}{*}{ TP } & Slope & -0.161 & -0.079 & -0.05 & -0.093 & -0.087 & -0.035 \\
\hline & & $p$ & 0.001 & 0.111 & 0.324 & 0.056 & 0.079 & 0.497 \\
\hline & & $\mathrm{R}^{2}$ & 0.657 & 0.160 & 0.065 & 0.223 & 0.192 & 0.031 \\
\hline & \multirow{3}{*}{ MP } & Slope & -0.137 & -0.078 & -0.108 & -0.13 & -0.093 & -0.126 \\
\hline & & p & 0.002 & 0.117 & 0.023 & 0.004 & 0.058 & 0.006 \\
\hline & & $\mathrm{R}^{2}$ & 0.479 & 0.047 & 0.300 & 0.431 & 0.219 & 0.405 \\
\hline
\end{tabular}




\subsection{The Interdependent Dynamics of Albedo \& LAI}

There existed negative relationships between LAI and all three measures of albedo (Table 2, Figure 7). When examined by LAI classes, all three albedo measures were higher for lower LAI classes (LAI < 1.5) on the MP than those on the TP, but were lower when LAI exceeded 2.0 (Table 1).

The negative relationships illustrated in Table 2 between LAI and albedo measures were modeled reasonably with a logarithm equation (Figure 8). For the MP, the correlation coefficient of determination $\left(\mathrm{R}^{2}\right)$ was $>0.95$, whereas on the TP, a similar degree of confidence was only achieved for albedo ${ }_{V I S}$. Again, the decrease in albedo with LAI was not apparent when LAI exceeded 1.5. Surprisingly, albedo $_{\text {NIR }}$ on the TP did not show a significant relationship with LAI and was stabilized at about $>2.50$ (Figure 8b). Additionally, the changes in three albedo measures with LAI were parallel on the MP (Figure 8a), but not on the TP (Figure 8b). The sharpest decrease was found for albedo ${ }_{\text {VIS }}$ on the TP when $\mathrm{LAI}<1.5$.

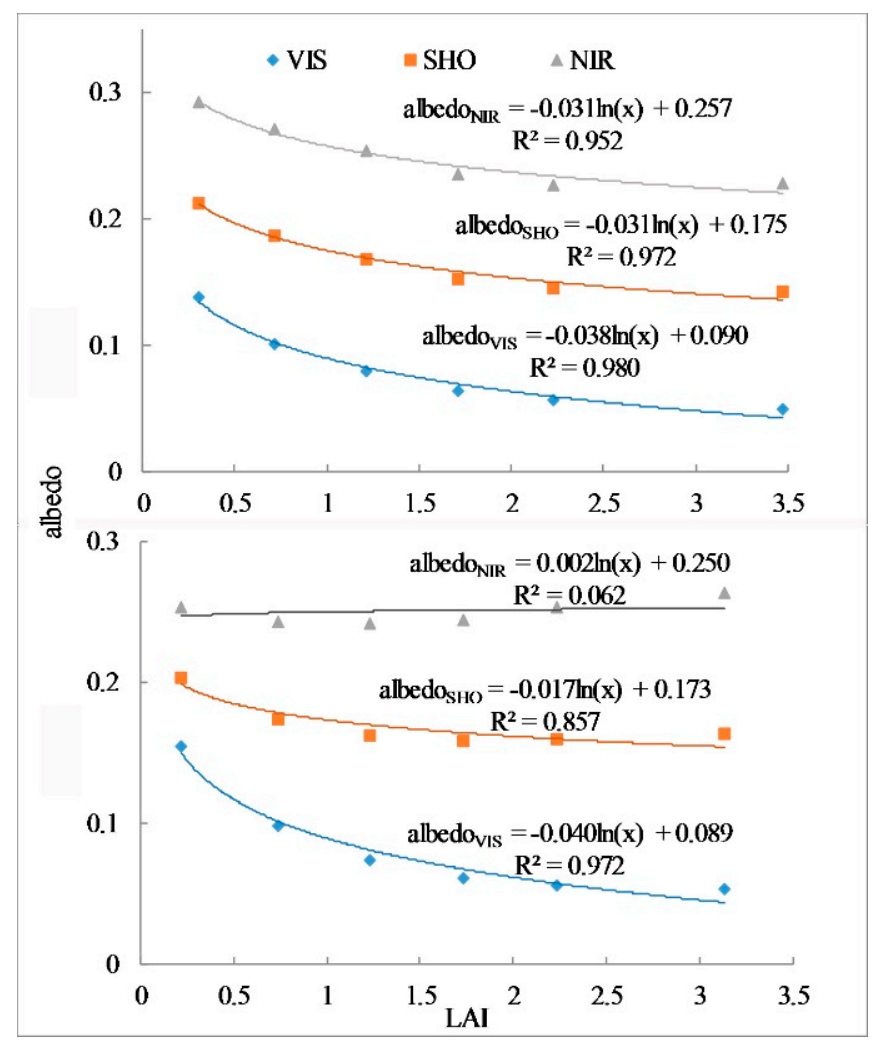

Figure 8. The logarithm regression of average annual albedo $_{(N I R, V I S, S H O)}$ retrieval as a function of estimated LAI classes (0.5 LAI steps), with stratified average data for the two plateaus.

\section{Discussion}

Albedo is a critical measure of the net radiation on land surfaces, which is the largest flux term of the energy balance. A minor change in albedo can result in significant changes in other energy fluxes, including latent heat, sensible heat, and soil heat fluxes. For example, a 1\% change in albedo at the peak net radiation (i.e., $1000 \mathrm{w} \mathrm{m}^{-2}$ ) on the TP means $10 \mathrm{w} \mathrm{m}^{-2}$ energy, which is equivalent to or greater than the average soil heat flux of the grasslands on both plateaus $[7,27,28,33]$. Our results indicate that the annual mean normalized albedo during the 17-year study period ranged from -1.935 (2013) to1.835 (2006) for the MP and from -1.288 (2010) to +2.154 (2002) for the TP (Figure 7, Table 3). Additionally, the spatial variation of land surface energy on the TP was higher than that on the MP. For the spatial variation, it decreased significantly, pointing to a maximum variation of $>8 \%$ during the study period for yearly and monthly albedo on both plateaus. These intra-annual variations are 
at similar magnitudes as those in boreal forests [9], a northern high latitude region [2], the South American Chaco [34], Berbet and Costa (2003) [35] in the tropical rain forests, and the Swiss Alps mountains in Europe [36]. These changes in albedo would not only influence the energy partitions of the local ecosystems, but, more importantly, also alter the feedback to the regional climate $[1,2,20,37]$.

Across the global land surface, cloud cover is the most direct and significant variable determining the spatial and temporal changes in land surface albedo. Land cover and change, meanwhile, has been reasoned as another major variable responsible for the changes in albedo $[5,31,38,39]$. Theoretically, high vegetation cover and dense canopies (i.e., high LAI) would intercept and absorb more incoming radiation, resulting in a lowered land surface albedo. This suggests that there should be a negative relationship between LAI and albedo. This relationship was confirmed in this study for both plateaus, except the relationship between LAI and albedo $_{\text {NIR }}$ on the TP (Figure 8). Generally, albedo ${ }_{N I R}$ reflectance increases with canopy development due to increased multiple scattering within the canopy [40], whereas improved surface roughness in the growing season for the grassland ecosystem increases diffuse reflectance, resulting in decreased albedo ${ }_{N I R}$. On the TP, although the albedo $_{N I R}$ showed a decreasing trend by year and month, a negative relationship between LAI class and albedo ${ }_{N I R}$ was not detected (Figures 2 and 3). It was clear that the change in NIR reflection may be affected by a combination of canopy characteristics and microclimate, on the TP, including the high altitude (i.e., thin atmosphere) $[25,28]$, canopy structure, soil moisture, permafrost, and other biophysical conditions. This interesting phenomenon begs further study. On the MP, the response of three albedo measures to LAI appeared the same (Figure 8a); the decrease in albedo with LAI was more pronounced at lower LAI $(<1.5)$ (Figure 8a), but on the TP, only albedo $_{V I S}$ with LAI was more pronounced at lower LAI $(<1.5)$ (Figure $8 \mathrm{~b}$ ).

As hypothesized, the LAI-albedo relationship was not spatially homogenous and is likely dependent of landform, different warming trends and contrasting climate, land cover type, and historical land usage (Figures 1-3). While it is a shortcoming of this study to not explore how the LAI-albedo relationship may co-vary with the above variables, it is clear that the high

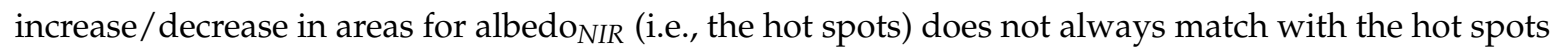
of LAI changes (Figures 2 and 3) at yearly or monthly scales on the TP. The rapid decrease in LAI in the southeast and increase in the northeast for the average annual LAI on the TP (Figure 2a) was due to the intensified land use and protection of the grasslands, respectively [7,41-43], where the annual mean albedo $\mathrm{V}_{V I S}$ hotspots also decreased in the southeast and increased in the northeast (Figure 3a) to achieve synergy with the LAI changes. Meanwhile, we succeed in detecting similar matches for the LAI-albedo $\mathrm{V}_{\text {IIS }}$ reverse synergistic change on the two plateaus. For example, a rapid increase in LAI in northern Mongolia and southeast Inner Mongolia (Figure 2a) was also observed with a high decrease in albedo ${ }_{V I S}$ (Figure 3a). On the TP, the annual change trends in both LAI and the three bands of albedo were found to be mismatches; only in the May did the area with increased/decreased LAI in the southeast/northwest match well with the decrease/increase in albedo ${ }_{V I S}$ (Figures $2 b$ and $3 b$ ). This result showed that on the TP, the correlation between LAI-albedo was more complex than on the MP, and such matches and mismatches need to be further explored with detailed in-situ data and analysis while considering land use practices (e.g., grazing, urbanization, agricultural expansion), as well as vegetation type, canopy structure, soil moisture, and other biophysical conditions [7].

The interdependent changes in LAI and albedo on the plateaus also showed large variations over time (Figures 6 and 7), with LAI of the MP showing an elevated LAI after 2010 (Figure 6a). Here, we found some major mismatches between LAI and albedo for several years, including 2003 on the TP and 2004 and 2015 on the MP, when albedo was significantly lower than the long term mean value (Figure 7a), while LAI did not show a similar level of increase (Figure 6a). When albedo was examined by month, it seemed that the interdependent relationships were not the same, with earlier months contributing more to the annual means on the TP, while later months (August-September) played a more vital role on the MP. The low annual albedo on the MP in 2003 seemed to be due to the extremely 
low value in July-September, whereas another extremely low value in 2015 was contributed to from those from May through August.

\section{Conclusions}

We compared and quantified the spatiotemporal changes in LAI and albedo on the two roofing plateaus in Eurasia using MODIS products from 2000 through 2016. We found that the frequency in LAI increase was stronger on the MP than on the TP. Additionally, the spatial variation of albedo on the TP was higher than that on the MP. While there existed a general negative logarithmic relationship between LAI and three measures of albedo on both plateaus, the relationships varied greatly in time and space. No relationship was found for LAI-albedo ${ }_{N I R}$ on the TP, likely because vegetation cannot absorb NIR. Additionally, TP has high altitude, different seasonal changes in soil moisture, permafrost, etc. that can indirectly affect NIR reflection. For the LAI-albedo ${ }_{V I S}$, more green leaves would absorb more shortwave radiation through photosynthesis and in turn decrease albedo ${ }_{V I S}$. Overall, $119.40 \times 10^{3} \mathrm{~km}^{2}(96.75 \%)$ and $28.35 \times 10^{3} \mathrm{~km}^{2}(48.53 \%)$ of the land area, respectively, of the Mongolian and Tibetan plateaus, experienced significant increases in LAI, while $585.59 \times 10^{3} \mathrm{~km}^{2}(96.72 \%)$ and $235.73 \times 10^{3} \mathrm{~km}^{2}(83.14 \%)$ of the land areas of the Mongolian and Tibetan Plateau, respectively, experienced decreases in albedo $_{V I S}$. More importantly, the relationships varied substantially across time and space. Substantial areas were found to have mismatches between changes in LAI and the three bands of albedo. Substantial additional efforts in the form of observational and/or experimental investigations are needed to explore the relationships by including the influences from landform, land cover, vegetation characteristics, and disturbances.

Author Contributions: J.C. and L.T. designed the study experiment and drafted the manuscript; L.T. performed data and statistical analysis. C.S. assisted in the data analysis and interpretation. All authors have contributed significantly and have participated sufficiently to take responsibility for this research.

Funding: This research was pointedly funded by the National Natural Science Foundation of China [41601100]; the Dynamics of Coupled Natural and Human Systems (CNH) Program of the NSF [\#1313761]; the US Department of Energy, Office of Science, Office of Biological and Environmental Research (DOE BER Office of Science DE-FC02-07ER64494); and the International Postdoctoral Exchange Fellowship Program 2015 by the Office of China Postdoctoral Council [the approval document number: No. 38 Document of OCPC, 2015].

Acknowledgments: We thank Connor Crank for editing the language of an earlier draft of the manuscript, and Chaonan Chen for helping to process data.

Conflicts of Interest: The authors declare no conflict of interest.

\section{References}

1. Davin, E.L.; de Noblet-Ducoudre, N. Climatic impact of global-scale deforestation: Radiative versus nonradiative processes. J. Clim. 2010, 23, 97-112. [CrossRef]

2. Loranty, M.M.; Berner, L.T.; Goetz, S.J.; Jin, Y.F.; Randerson, J.T. Vegetation controls on northern high latitude snow-albedo feedback: Observations and cmip5 model simulations. Glob. Chang. Biol. 2014, 20, 594-606. [CrossRef] [PubMed]

3. IPCC. Climate Change 2014. Synthesis Report Summary Chapter for Policymakers; Intergovernmental Panel on Climate Change: Geneva, Switzerland, 2014.

4. Bala, G.; Caldeira, K.; Wickett, M.; Phillips, T.J.; Lobell, D.B.; Delire, C.; Mirin, A. Combined climate and carbon-cycle effects of large-scale deforestation. Proc. Natl. Acad. Sci. USA 2007, 104, 6550-6555. [CrossRef] [PubMed]

5. Pielke, R.A. Land use and climate change. Science 2005, 310, 1625-1626. [CrossRef] [PubMed]

6. Rotenberg, E.; Yakir, D. Contribution of semi-arid forests to the climate system. Science 2010, 327, 451-454. [CrossRef] [PubMed]

7. You, Q.G.; Xue, X.; Peng, F.; Dong, S.Y.; Gao, Y.H. Surface water and heat exchange comparison between alpine meadow and bare land in a permafrost region of the Tibetan Plateau. Agric. For. Meteorol. 2017, 232, 48-65. [CrossRef] 
8. Brovkin, V.; Boysen, L.; Raddatz, T.; Gayler, V.; Loew, A.; Claussen, M. Evaluation of vegetation cover and land-surface albedo in MPI-ESM CMIP5 simulations. J. Adv. Model. Earth Syst. 2013, 5, 48-57. [CrossRef]

9. Lee, X.; Goulden, M.L.; Hollinger, D.Y.; Barr, A.; Black, T.A.; Bohrer, G.; Bracho, R.; Drake, B.; Goldstein, A.; $\mathrm{Gu}, \mathrm{L} . \mathrm{H}$; et al. Observed increase in local cooling effect of deforestation at higher latitudes. Nature 2011, 479, 384-387. [CrossRef] [PubMed]

10. Tian, L.; Chen, J.Q.; Zhang, Y.J. Growing season carries stronger contributions to albedo dynamics on the tibetan plateau. PLoS ONE 2017, 12, e0180559. [CrossRef] [PubMed]

11. Tian, L.; Zhang, Y.J.; Zhu, J.T. Decreased surface albedo driven by denser vegetation on the Tibetan Plateau. Environ. Res. Lett. 2014, 9, 104001. [CrossRef]

12. Planque, C.; Carrer, D.; Roujean, J.L. Analysis of MODIS albedo changes over steady woody covers in France during the period of 2001-2013. Remote Sens. Environ. 2017, 191, 13-29. [CrossRef]

13. Bounoua, L.; DeFries, R.; Collatz, G.J.; Sellers, P.; Khan, H. Effects of land cover conversion on surface climate. Clim. Chang. 2002, 52, 29-64. [CrossRef]

14. Jeong, S.-J.; Ho, C.-H.; Jeong, J.-H. Increase in vegetation greenness and decrease in springtime warming over East Asia. Geophys. Res. Lett. 2009, 36. [CrossRef]

15. Keeling, R.F.; Piper, S.C.; Heimann, M. Global and hemispheric $\mathrm{CO}_{2}$ sinks deduced from changes in atmospheric $\mathrm{O}_{2}$ concentration. Nature 1996, 381, 218-221. [CrossRef]

16. Myneni, R.B.; Hall, F.G.; Sellers, P.J.; Marshak, A.L. The interpretation of spectral vegetation indexes. IEEE Trans. Geosci. Remote Sens. 1995, 33, 481-486. [CrossRef]

17. Nemani, R.R.; Keeling, C.D.; Hashimoto, H.; Jolly, W.M.; Piper, S.C.; Tucker, C.J.; Myneni, R.B.; Running, S.W. Climate-driven increases in global terrestrial net primary production from 1982 to 1999. Science 2003, 300, 1560-1563. [CrossRef] [PubMed]

18. Peng, S.S.; Piao, S.L.; Ciais, P.; Myneni, R.B.; Chen, A.P.; Chevallier, F.; Dolman, A.J.; Janssens, I.A.; Penuelas, J.; Zhang, G.X.; et al. Asymmetric effects of daytime and night-time warming on northern hemisphere vegetation. Nature 2013, 501, 88. [CrossRef] [PubMed]

19. Li, Z.Y.; Wu, W.Z.; Liu, X.H.; Fath, B.D.; Sun, H.L.; Liu, X.C.; Xiao, X.R.; Cao, J. Land use/cover change and regional climate change in an arid grassland ecosystem of inner Mongolia, China. Ecol. Model. 2017, 353, 86-94. [CrossRef]

20. Zhao, X.; Hu, H.F.; Shen, H.H.; Zhou, D.J.; Zhou, L.M.; Myneni, R.B.; Fang, J.Y. Satellite-indicated long-term vegetation changes and their drivers on the Mongolian Plateau. Landsc. Ecol. 2015, 30, 1599-1611. [CrossRef]

21. Friedl, M.A.; McIver, D.K.; Hodges, J.C.F.; Zhang, X.Y.; Muchoney, D.; Strahler, A.H.; Woodcock, C.E.; Gopal, S.; Schneider, A.; Cooper, A.; et al. Global land cover mapping from MODIS: Algorithms and early results. Remote Sens. Environ. 2002, 83, 287-302. [CrossRef]

22. John, R.; Chen, J.Q.; Ou-Yang, Z.T.; Xiao, J.F.; Becker, R.; Samanta, A.; Ganguly, S.; Yuan, W.P.; Batkhishig, O. Vegetation response to extreme climate events on the Mongolian Plateau from 2000 to 2010. Environ. Res. Lett. 2013, 8, 035033. [CrossRef]

23. Myhre, G.; Stordal, F.; Johnsrud, M.; Diner, D.J.; Geogdzhayev, I.V.; Haywood, J.M.; Holben, B.N.; Holzer-Popp, T.; Ignatov, A.; Kahn, R.A.; et al. Intercomparison of satellite retrieved aerosol optical depth over ocean during the period September 1997 to December 2000. Atmos. Chem. Phys. 2005, 5, 1697-1719. [CrossRef]

24. Zhang, X.Y.; Friedl, M.A.; Schaaf, C.B.; Strahler, A.H.; Hodges, J.C.F.; Gao, F.; Reed, B.C.; Huete, A. Monitoring vegetation phenology using MODIS. Remote Sens. Environ. 2003, 84, 471-475. [CrossRef]

25. Wang, Z.S.; Schaaf, C.B.; Strahler, A.H.; Chopping, M.J.; Roman, M.O.; Shuai, Y.M.; Woodcock, C.E.; Hollinger, D.Y.; Fitzjarrald, D.R. Evaluation of MODIS albedo product (MCD43A) over grassland, agriculture and forest surface types during dormant and snow-covered periods. Remote Sens. Environ. 2014, 140, 60-77. [CrossRef]

26. Piao, S.L.; Wang, X.H.; Ciais, P.; Zhu, B.; Wang, T.; Liu, J. Changes in satellite-derived vegetation growth trend in temperate and boreal Eurasia from 1982 to 2006. Glob. Chang. Biol. 2011, 17, 3228-3239. [CrossRef]

27. Wang, K.C.; Liu, J.M.; Zhou, X.J.; Sparrow, M.; Ma, M.; Sun, Z.; Jiang, W.H. Validation of the MODIS global land surface albedo product using ground measurements in a semidesert region on the Tibetan Plateau. J. Geophys. Res.-Atmos. 2004, 109. [CrossRef]

28. Sturm, M.; Douglas, T.; Racine, C.; Liston, G.E. Changing snow and shrub conditions affect albedo with global implications. J. Geophys. Res.-Biogeosci. 2005, 110. [CrossRef] 
29. Enkhtur, K.; Pfeiffer, M.; Lkhagva, A.; Boldgiv, B. Response of moths (Lepidoptera: Heterocera) to livestock grazing in mongolian rangelands. Ecol. Indic. 2017, 72, 667-674. [CrossRef]

30. John, R.; Chen, J.Q.; Lu, N.; Wilske, B. Land cover/land use change in semi-arid Inner Mongolia: 1992-2004. Environ. Res. Lett. 2009, 4, 045010. [CrossRef]

31. Chen, J.; Wan, S.; Henebry, G.; Qi, J.; Gutman, G.; Sun, G.; Kappas, M. Dryland East Asia: Land Dynamics Amid Social and Climate Change; Higher Education Press: Beijing, China, 2013.

32. Zhang, Z.D.; Yang, Q.Y. Physical Geography of Xizang; Science Press: Beijing, China, 1982. (In Chinese)

33. Shao, C.; Li, L.; Dong, G.; Chen, J. Spatial variation of net radiation and its contribution to energy balance closures in grassland ecosystems. Ecol. Process. 2014, 3, 7. [CrossRef]

34. Houspanossian, J.; Gimenez, R.; Jobbagy, E.; Nosetto, M. Surface albedo raise in the South American Chaco: Combined effects of deforestation and agricultural changes. Agric. For. Meteorol. 2017, 232, 118-127. [CrossRef]

35. Loescher, H.W.; Gholz, H.L.; Jacobs, J.M.; Oberbauer, S.F. Energy dynamics and modeled evapotranspiration from a wet tropical forest in Costa Rica. J. Hydrol. 2005, 315, 274-294. [CrossRef]

36. Rangwala, I.; Miller, J.R. Climate change in mountains: A review of elevation-dependent warming and its possible causes. Clim. Chang. 2012, 114, 527-547. [CrossRef]

37. Krishnaswamy, J.; John, R.; Joseph, S. Consistent response of vegetation dynamics to recent climate change in tropical mountain regions. Glob. Chang. Biol. 2014, 20, 203-215. [CrossRef] [PubMed]

38. Taylor, P.C.; Kato, S.; Xu, K.M.; Cai, M. Covariance between arctic sea ice and clouds within atmospheric state regimes at the satellite footprint level. J. Geophys. Res.-Atmos. 2015, 120, 12656-12678. [CrossRef] [PubMed]

39. Wild, M.; Hakuba, M.Z.; Folini, D.; Schar, C.; Long, C. New estimates of the earth radiation budget under cloud-free conditions and cloud radiative effects. Radiat. Process. Atmos. Ocean 2017, 1810, 090012.

40. Gates, D.M. Energy, plants, and ecology. Ecology 1965, 46, 1-13. [CrossRef]

41. Wang, S.Y.; Yang, B.J.; Yang, Q.C.; Lu, L.L.; Wang, X.Y.; Peng, Y.Y. Temporal trends and spatial variability of vegetation phenology over the Northern Hemisphere during 1982-2012. PLoS ONE 2016, 11, e0157134. [CrossRef] [PubMed]

42. Xue, X.; Guo, J.; Han, B.S.A.; Sun, Q.W.; Liu, L.C. The effect of climate warming and permafrost thaw on desertification in the Qinghai-Tibetan Plateau. Geomorphology 2009, 108, 182-190. [CrossRef]

43. Yi, S.H.; Zhou, Z.Y.; Ren, S.L.; Xu, M.; Qin, Y.; Chen, S.Y.; Ye, B.S. Effects of permafrost degradation on alpine grassland in a semi-arid basin on the Qinghai-Tibetan Plateau. Environ. Res. Lett. 2011, 6, 045403. [CrossRef] 